FOLIA POMERANAE UNIVERSITATIS TECHNOLOGIAE STETINENSIS

Folia Pomer. Univ. Technol. Stetin., Oeconomica 2018, 346(92)3, 5-16

Włodzimierz DELUGA

\title{
ZNACZENIE MARKETINGU EKOLOGICZNEGO W ZACHOWANIU CZYSTOŚCI WÓD MORZA BAKTYCKIEGO
}

\section{THE ROLE OF ECOLOGICAL MARKETING IN PRESERVING THE PURITY OF WASTERS OF THE BALTIC SEA}

Zakład Marketingu i Przedsiębiorczości, Politechnika Koszalińska

ul. Eugeniusza Kwiatkowskiego 6E, 75-343 Koszalin, ORCID: 0000-0001-6408-4766

e-mail: wlodzimierz.deluga@tu.koszalin.pl

\begin{abstract}
Summary. This article was devoted to the subject of ecological marketing, as well as activities undertaken by Poland within the framework of the preservation of purity for waters of the Baltic Sea. Moreover, it presented the initiatives implemented the Polish authorities and the results of a diagnostic survey preceded by a theoretical part and an analysis concerning the condition of the Baltic Sea's natural environment.
\end{abstract}

Słowa kluczowe: marketing, marketing ekologiczny, środowisko naturalne, Morze Bałtyckie, projekt, przedsięwzięcie, kampania społeczna.

Key words: marketing, ecological marketing, natural environment, Baltic Sea, project, undertaking, public campaign.

\section{WSTĘP}

Ekologia w dzisiejszych czasach jest dziedziną naukową, która w coraz większym stopniu może wpływać na promowanie oraz kreowanie pozytywnego wizerunku m.in. miasta, państwa, regionu turystycznego. Dlatego marketing ekologiczny jest jednym z najbardziej dynamicznie rozwijających się nurtów w dziedzinie marketingu.

Celem opracowania jest przybliżenie tematyki marketingu ekologicznego, problematyki ochrony środowiska morskiego, a także zaprezentowanie realizowanych wybranych projektów proekologicznych dotyczących czystości wód Morza Bałtyckiego. Kluczowym problemem badawczym jest poszukiwanie odpowiedzi na pytanie: Co uczynić, by poprawić stan czystości Morza Bałtyckiego? Najpierw należy odpowiedzieć na pytania o to, na ile dotychczasowe działania władz państw basenu Morza Bałtyckiego skutecznie poprawiają czystość Bałtyku i jaka jest świadomość społeczeństwa w zakresie zagrożeń. Uwzględniając dostępność danych statystycznych, posłużono się analizą ilościową, jakościową, sondażem diagnostycznym oraz obserwacjami instytucji i organizacji pozarządowych. W artykule przedstawiono działania, które wpływają na poprawę stanu jakości wód Morza Bałtyckiego oraz zaprezentowano wyniki badań opinii respondentów na temat działalności władz państwa polskiego w tym zakresie.

Wzmożona działalność człowieka spowodowała konieczność ochrony środowiska. Człowiek musi ograniczyć swoje postępowanie, by móc w dalszym ciągu wykorzystywać zasoby Ziemi, w tym zasoby Bałtyku. Tempo, w jakim człowiek wytwarza różnego rodzaju zanieczyszczenia, wymusza zmianę w organizacji polityki społeczno-gospodarczej. 


\section{SPECYFIKA MARKETINGU EKOLOGICZNEGO}

Rozwój zrównoważony oznacza konieczność zachowania równowagi w środowisku przyrodniczym i technicznym, a także równowagi duchowej człowieka. W literaturze polskiej spotykamy się z wieloma jego określeniami: rozwój zrównoważony, trwały, samopodtrzymujący się, ekorozwój. Rozwój zrównoważony (ang. sustainable development) jest to rozwój rozumiany integralnie w sensie ekologicznym, kulturowym i ekonomicznym (Kozłowski 2005). Dbałość o środowisko naturalne jest powinnością współczesnej cywilizacji. Zadanie to spoczywa także na działaniach marketingowych.

Koncepcja marketingu ekologicznego wywodzi się z idei marketingu społecznego. Marketing społeczny jest narzędziem zarządzania zmianą społeczną, który uwzględnia projektowanie, wdrażanie oraz kontrolę programów, których głównym celem jest wzrost akceptacji danego produktu społecznego w danej grupie społecznej (Zaremba-Warnke 2009). W ramach marketingu społecznego wyróżnia się m.in. marketing ekologiczny, który nazywany jest również ekomarketingiem, marketingiem zielonym czy marketingiem środowiskowym. Innymi ważnymi pojęciami związanymi z marketingiem ekologicznym są pojęcia ekologii, ekologii społecznej oraz świadomości ekologicznej.

Pojęcie „ekologia” pochodzi z języka greckiego i powstało z połączenia dwóch wyrazów: "oikos” - dom i „logos” - wiedza, nauka. Ekologia jest nauką, która bada strukturę oraz funkcjonowanie przyrody, a także zajmuje się badaniem wzajemnych relacji, które występują pomiędzy organizmami a otaczającym je środowiskiem żywym i martwym (Małachowski 2011). W znaczeniu potocznym bardzo często ekologia jest nauką, która zajmuje się ochroną środowiska, jednakże jest to błędne rozumienie, ponieważ to sozologia jest nauką dotyczącą ochrony środowiska. Ekologia zajmuje się badaniem zależności występujących pomiędzy człowiekiem, społeczeństwem a środowiskiem naturalnym. Ma to na celu tworzenie pozytywnych relacji pomiędzy społeczeństwem a środowiskiem naturalnym oraz zwrócenie uwagi na postępującą degradację środowiska. Dlatego głównym celem ekologii społecznej jest przeciwdziałanie degradacji przyrody poprzez kształtowanie postaw proekologicznych oraz zwiększenie odpowiedzialności społeczeństwa za środowisko naturalne.

Interesującym pojęciem związanym z marketingiem ekologicznym jest pojęcie świadomości ekologicznej. Świadomość to zdolność reagowania na różne zjawiska. Świadomość ekologiczna jest więc stosunkiem człowieka do środowiska naturalnego, a także systemem wartości i przekonań, jakimi kieruje się człowiek w swoim postępowaniu wobec środowiska naturalnego (Kiełczewski 1999). Matczak (2000) stwierdza, że świadomość ekologiczna to „kategoria opisowa, która wskazuje, jak konkretna grupa społeczna czy też całe społeczeństwo widzi swoje miejsce w środowisku naturalnym i jak postrzega swoje związki ze środowiskiem przyrodniczym" (s. 54). Leśniak (2001) definiuje ekomarketing jako proces zarządzania, który ma na celu rozpoznawanie, przewidywanie oraz zaspokajanie proekologicznych potrzeb poprzez oferowanie produktów i usług, które są przyjazne dla środowiska naturalnego.

Koncepcja marketingu ekologicznego pojawiła się na przełomie lat 80. i 90. ubiegłego wieku, natomiast w Polsce jest ona stosunkowo nowa. Jednakże z roku na rok można obserwować zwiększone zainteresowanie tą tematyką. Spowodowane jest to przede wszystkim zwiększonym poziomem świadomości ekologicznej społeczeństwa. 
Duży wpływ na rozwój marketingu środowiskowego mają również uchwalane przepisy regulujące dziedzinę ochrony środowiska. Międzynarodowe oraz krajowe regulacje dotyczą głównie tego, aby zmniejszyć produkcję niebezpiecznych, szkodliwych, trujących towarów oraz produktów ubocznych procesu produkcyjnego.

Ważną rolę w rozwoju ekomarketingu odgrywa również koncepcja społecznie odpowiedzialnego biznesu, w której szczególnie miejsce zajmuje troska o środowisko naturalne. Działalność przedsiębiorstw jest w jakimś stopniu powiązana z degradacją środowiska, dlatego przedsiębiorstwa muszą podejmować sprecyzowane działania na rzecz jego ochrony. Warto tutaj zaznaczyć, że działania marketingowe i działania na rzecz ochrony środowiska nie muszą się wykluczać; mogą ze sobą współgrać, a nawet dobrze by było, jakby były ze sobą skoordynowane, ponieważ sprzyja to zarówno realizacji celów przedsiębiorstwa, jak i generuje korzyści dla środowiska naturalnego oraz całego społeczeństwa.

Przedsiębiorstwa w dzisiejszych czasach chcą działać w sposób społecznie odpowiedzialny, dlatego w swojej działalności kierują się nie tylko interesem własnym, ale także interesem społeczeństwa. Ekomarketing można nazwać także procesem, który składa się z projektowania i wytwarzania dóbr posiadających wartość ekologiczną. Obserwuje się zwiększający się poziom świadomości ekologicznej społeczeństwa, który można określić jako stosunek człowieka do środowiska naturalnego, a także jako zbiór wartości, którymi kieruje się człowiek w swoim postępowaniu wobec przyrody.

\section{ŚRODOWISKO PRZYRODNICZE MORZA BALTYCKIEGO}

Morze Bałtyckie jest płytkim morzem śródlądowym, które położone jest na szelfie kontynentalnym w północnej części Europy. O śródlądowym charakterze Morza Bałtyckiego świadczy to, że ze wszystkich stron jest otoczone lądem; z Morzem Północnym łączą ją wąskie cieśniny duńskie: Sund, Wielki Bełt oraz Mały Bełt, a także cieśniny Kattegat i Skagerrak.

Powierzchnia Morza Bałtyckiego wraz z cieśniną Kattegat zajmuje ok. 415 tys. km². Największą jego część tworzy Bałtyk Właściwy, który zajmuje 209930 km² powierzchni. Bałtyk Właściwy rozdziela się na północy, dzięki czemu powstają Zatoka Fińska i Morze Botnickie, które zwęża się w Zatokę Botnicką. Na wschodzie z kolei rozdziela się, tworząc Zatokę Ryską. Na zachodzie Bałtyk Właściwy graniczy z obszarem, który nazywany jest Sundem i Morzem Bełtów. Po drugiej stronie wysp znajduje się szeroka cieśnina Kattegat, której powierzchnia jest wliczana do powierzchni Morza Bałtyckiego. Akweny Morza Bałtyckiego przedstawia tab. 1.

Żadna część Morza Bałtyckiego nie ma większej średniej głębokości od $65 \mathrm{~m}$, a ogólna średnia głębokość Bałtyku wynosi $52 \mathrm{~m}$. Oznacza to, że Morze Bałtyckie jest bardzo płytkim akwenem wodnym. Zauważyć również można, że średnia głębokość Sundu oraz Morza Bełtów wynosi 14,3 m; maksymalna głębokość wynosi tylko 38m. Takie wartości świadczą o tym, że wymiana wód pomiędzy Morzem Bałtyckim, a Kattegatem i Morzem Północnym jest bardzo utrudniona oraz ograniczona. 
Tabela 1. Akweny Morza Bałtyckiego w liczbach

\begin{tabular}{|l|c|c|c|c|}
\hline \multicolumn{1}{|c|}{ Akweny } & $\begin{array}{c}\text { Powierzchnia } \\
{\left[\mathrm{km}^{2}\right]}\end{array}$ & $\begin{array}{c}\text { Objętość wody } \\
{\left[\mathrm{km}^{3}\right]}\end{array}$ & $\begin{array}{c}\text { Maksymalna } \\
\text { głębokość }[\mathrm{m}]\end{array}$ & $\begin{array}{c}\text { Średnia głębokość } \\
{[\mathrm{m}]}\end{array}$ \\
\hline Zatoka Botnicka & 36260 & 1481 & 156 & 40,8 \\
\hline Morze Botnickie & 79257 & 4448 & 294 & 61,7 \\
\hline Zatoka Fińska & 29498 & 1098 & 123 & 37,2 \\
\hline Zatoka Ryska & 17913 & 406 & 51 & 22,7 \\
\hline Bałtyk właściwy & 209930 & 13045 & 459 & 62,1 \\
\hline $\begin{array}{l}\text { Sund i Morze } \\
\text { Bełtów }\end{array}$ & 20121 & 287 & 38 & 14,3 \\
\hline Kattegat & 22287 & 515 & 109 & 23,1 \\
\hline
\end{tabular}

Źródło: Cech morfometryczne, http://www.naszbaltyk.pl/cechy_morfometryczne.html.

Średnie zasolenie Morza Bałtyckiego wynosi 7,5\%o, oceanu natomiast - 36,6\%o. Sytuację tlenową oraz wzrost poziomu zasolenia Morza Bałtyckiego poprawiają wlewy, a więc takie sytuacje, gdy dochodzi do przelewania się wód pochodzenia oceanicznego, które są dobrze natlenione. Niestety dochodzi do nich tylko raz na kilka lat i to tylko podczas silnych sztormów.

Płytkie cieśniny mają duży wpływ na niskie zasolenie Morza Bałtyckiego, ponieważ utrudniają dopływ słonych wód z Oceanu Atlantyckiego. Morze Bałtyckie jest morzem zimnym. Jego średnia temperatura w okresie letnim wynosi ok. $15^{\circ} \mathrm{C}$, natomiast w zimie $-0-2^{\circ} \mathrm{C}$.

Fauna i flora Morza Bałtyckiego jest dosyć uboga, co oznacza, że w Morzu Bałtyckim występuje niewiele gatunków zwierząt oraz roślin. W Morzu Bałtyckim, pomimo niskiego zasolenia wód, istnieje życie, które tworzy ciekawy ekosystem. W skład tego ekosystemu wchodzą takie grupy środowiskowe, jak: fitoplankton, fitobentos, zooplankton, zoobentos, nekton oraz awifauna.

Fitoplankton są to jednokomórkowe samożywne organizmy, które unoszą się biernie w prześwietlonej warstwie wodnej. Są to najczęściej organizmy o rozmiarze od kilku tysięcznych milimetra do około $2 \mathrm{~mm}$. Do fitoplanktonu Morza Bałtyckiego można zaliczyć głównie okrzemki oraz bruzdnice. Aktualnie w Bałtyku stwierdzono obecność ponad 700 gatunków, które zaliczane są do fitoplanktonu.

Zooplankton składa się z protozooplanktonu, czyli z organizmów jednokomórkowych oraz z metazooplanktonu, czyli z organizmów o bardziej złożonej budowie.

Skład i liczebność zooplanktonu zmieniają się wraz z porami dnia. Najwięcej zooplanktonu na powierzchni morza występuje w nocy, natomiast w ciągu dnia jest go tam bardzo mało.

Fitobentos tworzą rośliny, które porastają dno morskie. Są to przede wszystkim organizmy, który zamieszkują strefę przybrzeżną. Roślinność morską stanowią mikro- oraz makroglony, a także rośliny kwiatowe, które rosną na dnie zbiornika wodnego.

Zoobentos są to zwierzęta, które żyją na dnie morskim bądź są zagrzebane w osadzie. Ze względu na ich wielkość można dokonać podziału na makrozoobentos i meiobentos.

W Morzu Bałtyckim żyją obecnie tylko cztery gatunki ssaków morskich. Są to trzy gatunki fok: szara, obrączkowana i pospolita oraz morświn, a więc przedstawiciel rodziny delfinów.

Nekton są to wszystkie duże zwierzęta, które aktywnie poruszają się w toni wodnej; do nektonu zalicza się ryby oraz ssaki. 
W Morzu Bałtyckim można zaobserwować 26 gatunków ryb morskich oraz kilka gatunków ryb słodkowodnych i dwuśrodowiskowych.

Awifauna - ptaki; są ostatnim gatunkiem zwierząt, które zamieszkują wybrzeża Morza Bałtyckiego. Obecnie liczbę tych gatunków szacuje się na około 30; można do nich zaliczyć m.in.: alki, kaczki, tracze, rybitwy, mewy, siewkowce, nury, perkozy i kormorany czarne.

Fauna i flora Bałtyku jest uboga, ponieważ Morze Bałtyckie jest akwenem płytkim, zimnym oraz słabo zasolonym. Charakterystyczne dla Morza Bałtyckiego jest to, że im dalej od Kattegatu i cieśnin duńskich, gdzie notowany jest największy poziom zasolenia wody, tym mniejsza jest liczba występujących gatunków. Specyficzną cechą Bałtyku jest także występowanie nie tylko gatunków ryb słonowodnych, ale także gatunków dwuśrodowiskowych oraz ryb słodkowodnych.

\section{ZANIECZYSZCZENIE MORZA BAŁTYCKIEGO}

Zanieczyszczanie to świadome lub nieświadome wprowadzanie do środowiska naturalnego substancji lub energii, które są szkodliwe dla fauny oraz flory. Zanieczyszczenia stanowią również zagrożenie dla zdrowia człowieka. Zanieczyszczenia wód zmniejszają walory rekreacyjne zbiorników wodnych. Źródła zanieczyszczeń akwenów wodnych można podzielić na dwie grupy - na źródła lądowe oraz na źródła morskie. Do źródeł lądowych zalicza się zanieczyszczenia pochodzące z przemysłu, gospodarki komunalnej, rolnictwa oraz komunikacji lądowej. Natomiast do źródeł morskich można zaliczyć zanieczyszczenia, które pochodzą z portów, przemysłu wydobywczego oraz żeglugi morskiej.

Tabela 2. Rodzaje zanieczyszczeń oraz ich główne źródła

\begin{tabular}{|l|l|}
\hline \multicolumn{1}{|c|}{ Rodzaje zanieczyszczeń } & \multicolumn{1}{c|}{ Główne źródła } \\
\hline $\begin{array}{l}\text { substancje biogeniczne (główne związki azotu i fosforu } \\
\text { oraz materia organiczna) }\end{array}$ & $\begin{array}{l}\text { rolnictwo (nawozy sztuczne i hodowla zwierzą), prze- } \\
\text { mysł i komunikacja, gospodarka komunalna }\end{array}$ \\
\hline $\begin{array}{l}\text { substancje toksyczne (metale ciężkie takie jak kadm, } \\
\text { rtęć, ołów oraz pestycydy) }\end{array}$ & $\begin{array}{l}\text { przemysł (produkty uboczne procesów produkcyjnych), } \\
\text { gospodarka komunalna (spalanie śmieci), komunikacja } \\
\text { (spalanie paliw) oraz rolnictwo (zjawisko jego che- } \\
\text { mizacji) }\end{array}$ \\
\hline $\begin{array}{l}\text { zanieczyszczenie ropopochodne (ropa, jej pochodne } \\
\text { oraz produkty spalania) }\end{array}$ & $\begin{array}{l}\text { przemysł, komunikacja, gospodarka komunalna, że- } \\
\text { gluga morska, działalność portów oraz katastrofy } \\
\text { i wypadki }\end{array}$ \\
\hline skażenia sanitarne (mikrobiologiczne) & $\begin{array}{l}\text { gospodarka komunalna (ścieki), rolnictwo (hodowla } \\
\text { zwierząt), przemysł (odpady spożywcze) }\end{array}$ \\
\hline substancje radioaktywne & elektrownie jądrowe (katastrofy) \\
\hline inne (głównie śmieci) & gospodarka komunalna i przemysł \\
\hline
\end{tabular}

Źródło: opracowano na podstawie analizy literatury.

Jednym z największych problemów mórz jest proces eutrofizacji. Jest to zjawisko, które polega na tym, że zbiorniki wodne są wzbogacane przez składniki odżywcze, takie jak azot i fosfor. Zjawisko to występuje naturalnie lub jest wynikiem działalności człowieka, co powoduje rozwój fitoplanktonu, dzięki czemu wzrasta żyzność wody. 
Morze Bałtyckie jest zbiornikiem wodnym, które szczególnie jest zagrożone procesem eutrofizacji. Spowodowane jest to przede wszystkim tym, że aż 17\% obszaru Europy położne jest w obrębie zlewiska Bałtyku. Eutrofizacja w Morzu Bałtyckim spowodowana jest głównie zbyt dużą ilością zanieczyszczeń komunalnych oraz przemysłowych, które trafiają rzekami do morza. Wąskie cieśniny duńskie powodują, że wymiana wód z Oceanem Atlantyckim jest bardzo utrudniona, co potęguje eutrofizację Bałtyku.

W okresie II wojny światowej w Bałtyku była zatopiona broń chemiczna. Szacuje się, że na dnie Bałtyku ukryto od 40 tys. do nawet 300 tys. t amunicji. Dane te są szacunkowe, ponieważ wszelkie informacje $z$ powodu decyzji politycznych były objęte embargiem przez 50 lat (Bomba na dnie Bałtyku, http://biznes.onet.pl/wiadomosci/swiat/bomba-na-dniebaltyku/n6nz76).

Zatopiona broń chemiczna w wodach Morza Bałtyckiego jest tykającą bombą ekologiczną, która może wybuchnąć w każdej chwili. Stanowi ona bardzo duże zagrożenie nie tylko dla ekosystemu Bałtyku, ale także dla zdrowia i życia mieszkańców bałtyckiego wybrzeża. Dotychczas odkryto ok. 60 miejsc, gdzie zatopiona jest broń chemiczna. Największe jej skupiska znajdują się w okolicach Głębi Bornholskiej, Małego Bełtu oraz w południowozachodniej część Głębi Gotlandzkiej. Część tej amunicji znajduje się w polskiej strefie ekonomicznej w okolicach Kołobrzegu, Darłowa oraz Helu, a także w Głębi Gdańskiej oraz Rynnie Słupskiej.

Wraz z rozwojem technologii powstają nowe warianty neutralizacji zasobów broni chemicznej na dnie Morza Bałtyckiego. Obecnie proponuje się trzy warianty:

- fizyczny (pokrycie miejsca z bronią chemiczną warstwą tworzywa sztucznego lub betonu);

- chemiczny (użycie odkażalników);

- fizykochemiczny (spalenie amunicji w łuku plazmowym).

Zjawisko występowania broni chemicznej w wodach Morza Bałtyckiego jest zjawiskiem niezwykle groźnym, ponieważ szacuje się, że w przypadku uwolnienia się ze zbiorników ok. $15 \%$ substancji chemicznych życie w Bałtyku oraz wzdłuż jego wybrzeża uległoby całkowitemu wyginięciu na 100 lat.

Innymi substancjami, które wpływają na duże zanieczyszczenie Morza Bałtyckiego, są substancje toksyczne, w tym głównie metale ciężkie. Substancje toksyczne po przedostaniu się do wód Morza Bałtyckiego zostają poddane procesom fizycznym, chemicznym i biologicznym. Oznacza to więc, że substancje te rozdzielają się pomiędzy wodę, osady, a organizmy żywe.

Morze Bałtyckie jest akwenem wodnym, które jest bardzo zanieczyszczone. W największych ilościach do Bałtyku trafiają związki azotu, fosforu, potasu oraz sodu, związki toksyczne (głównie metale ciężkie), substancje ropopochodne oraz inne zanieczyszczenia (głównie śmieci). Na dnie Morza Bałtyckiego tworzą się tzw. pustynie tlenowe, które są pozbawione życia. Innymi zagrożeniami są substancje toksyczne oraz ropopochodne. Substancje te związane są z działalnością człowieka i pochodzą z przemysłu, rolnictwa, gospodarki komunalnej, a także żeglugi morskiej i platform naftowych oraz gazowych. 


\section{OCHRONA MORZA BAŁTYCKIEGO A ŚWIADOMOŚĆ POTRZEBY DZIAŁAŃ OCHRONNYCH}

Bałtycki plan działania HELCOM to przykład inicjatywy, która została zainicjowana w ramach regionalnej strategii, mającej doprowadzić do poprawy stanu środowiska Morza Bałtyckiego. Program ten był tworzony blisko dwa lata przez państwa będące członkami Komisji Helsińskiej (HELCOM); stanowi pierwszy na świecie program działań na rzecz ochrony morza (Bałtycki Plan Działania, http://www.bsap.pl).

W ramach tej strategii HELCOM dąży się do znacznego ograniczenia zanieczyszczeń Bałtyku oraz przywrócenia jego dobrego stanu ekologicznego do roku 2021. Bałtycki plan działania został przyjęty przez przedstawicieli następujących rządów: Polski, Litwy, Łotwy, Estonii, Danii, Niemiec, Rosji, Szwecji i Finlandii. Konwencja była sygnowana 15 listopada 2007 roku w Krakowie. Program przyjął również przedstawiciel Komisarza UE ds. Środowiska.

Sygnatariusze programu, wskazywali na to, że inicjatywa ta ma działać na zasadzie rekomendacji, czyli moralnych, a także częściowo prawnych zobowiązań poszczególnych krajów HELCOM. Celem monitorowania postępów w zakresie realizacji bałtyckiego planu działania doszło do powołania specjalnej instytucji na posiedzeniu HELCOM.

W ramach programu konwencji zawarte zostały działania ujęte w czterech częściach, które zostały uznane za najważniejsze dla ochrony środowiska morskiego Bałtyku. Postanowiono się skupić na następujących celach strategicznych (Bałtycki Plan Działania, http://www.bsap.pl):

- na zapobieganiu eutrofizacji, czyli nadmiernemu wzrostowi substancji odżywczych, które przyczyniają się do nienaturalnego zakwitania glonów i co za tym idzie - do powstawania stref beztlenowych;

- na przeciwdziałaniu zrzutów substancji niebezpiecznych, w tym rakotwórczych i toksycznych dioksyn (m.in. azotu, rtęci i fosforu);

- na zapewnieniu przyjaznego dla środowiska transportu morskiego;

- na ochronie bioróżnorodności (bezpieczeństwo ewolucji oraz trwałości układów podtrzymujących życie w biosferze).

HELCOM jest jedynie deklaracją niezobowiązującą rządów państw bałtyckich do inicjowania konkretnych działań mających chronić Morze Bałtyckie.

Od początku lat dziewięćdziesiątych XX w. obserwuje się wzmocnienie międzynarodowego reżimu odnoszącego się do zagadnień związanych z ochroną Morza Bałtyckiego.

Wiele inicjatyw związanych z ochroną środowiska Morza Bałtyckiego realizuje się przy dużym wsparciu UE (np. z funduszu spójności). Przykładem jest projekt realizowany przez gminę Gdańsk w latach 2004-2008, który polegał na dążeniu do ograniczenia ładunków zanieczyszczeń wnoszonych do Bałtyku z obszaru miasta. Na działania związane z tym celem wydano $400 \mathrm{mln}$ zł.

Na obszarze Gdyni realizowany jest projekt "Ochrona wód Zatoki Gdańskiej - budowa i modernizacja systemu odprowadzania wód opadowych". W 2012 roku zainicjowano realizację drugiego etapu, w ramach czego wybudowano i zmodernizowano istniejące części systemu odprowadzania wód opadowych, kanałów deszczowych oraz przepompowni w śródmieściu Gdyni ( $\mathrm{Na}$ ratunek środowisku, http://trojmiasto.wyborcza.pl/trojmiasto/ 1,72938,12683051,Na_ratunek_srodowisku.htm|\#ixzz4Nzd1sZSH). 
Wiele istotnych informacji na temat zaangażowania władz polskich w ochronę Morza Bałtyckiego można odnaleźć w różnego rodzaju dokumentach strategicznych. Stanowią one ważne źródło wiedzy na temat działań władz polskich w zakresie promowania idei dbania o środowisko naturalne Bałtyku. Przykładem może być Raport z realizacji polityki morskiej RP w 2015 r.

W dokumencie tym zaznaczono, iż podstawowymi celami środowiskowymi w odniesieniu do środowiska morskiego stają się: poprawa jakości wód morskich, w szczególności poprzez ochronę i zachowanie środowiska morskiego; zapobieganie jego degradacji, a także stopniowa eliminacja zanieczyszczenia środowiska morskiego w celu wykluczenia znacznego wpływu na biologiczną różnorodność morską i ekosystemy morskie.

Ministerstwo Środowiska oraz inne podmioty władzy publicznej, zaangażowane w dbanie o czystość Morza Bałtyckiego, często angażują się w działania realizowane poprzez różnego typu organizacje pozarządowe. Ich udział polega na objęciu danej inicjatywy honorowym patronatem czy sponsoringiem.

Przykładem akcji, którą rokrocznie wspiera Ministerstwo Środowiska, jest akcja sprzątania Bałtyku. W 2013 r. na stronach Ministerstwa można było przeczytać o kampanii „Bałtyk też może". W ramach tej inicjatywy członkowie Fundacji Nasza Ziemia wraz z Barefoot Projekt Czysta Plaża i z Rowerowym Rajdem dla Bałtyku m.in. uświadamiali turystom oraz mieszkańcom wybrzeża, jak istotne znaczenie ma dbanie o Morze Bałtyckie - o jego zasoby oraz różnorodność biologiczną. W ramach tych działań prowadzone były lekcje pokazowe, w trakcie których edukowano osoby zainteresowane, w jaki sposób można przyczynić się do poprawy stanu Bałtyku. Poprzez edukację i zabawę Fundacja zachęcała społeczeństwo do aktywnego działania na rzecz ochrony Bałtyku - unikatowego i wrażliwego ekosystemu, który jest miejscem wypoczynku wielu Polaków (Finał kampanii Bałtyk też może!, http://www.naszaziemia.pl/aktualnosci/baltyk-tez-moze-finalowy-weekend-kampanii.html).

Oprócz akcji polegających na sprzątaniu plaż Fundacji Nasza Ziemia organizowała działania informacyjno-edukacyjne poświęcone bioróżnorodności Morza Bałtyckiego.

Inną kampanią, w którą zaangażowało się Ministerstwo Środowiska, była kampania "Czyste plaże - nowe życie puszek”.

Za główny cel projektu „Czyste plaże” uznano promowanie ekologicznego wypoczynku, segregowania śmieci i pozostawiania po sobie porządku na miejscu wypoczynku.

W ramach tej akcji przeprowadzono co najmniej 240 warsztatów dla kolonistów. W trakcie wcześniejszych akcji członkowie fundacji Recall przeprowadzili ok. 771 warsztatów edukacyjnych dla ponad 40 tysięcy młodych wczasowiczów.

Dla osób dorosłych przygotowano plakaty i kartki pocztowe (zawierające informacje o punktach skupu surowców wtórnych w pasie wybrzeża Bałtyku). Kampania była współfinansowana przez Unię Europejską w 77\%, reszta środków pochodziła od stowarzyszeń działających na rzecz ochrony środowiska i promocji ekologii, a także od samorządów terytorialnych.

Ministerstwo Środowiska jest obecne na najważniejszych serwisach społecznościowych, takich jak: Facebook, Twitter oraz YouTube. Media te mają do spełnienia przede wszystkim funkcje informacyjne. Za ich pośrednictwem zarządzający kontem Ministerstwa przekazują wiadomości na temat organizowanych akcji czy publikują relacje z kampanii społecznych. 
W ramach czystości wód Morza Bałtyckiego podejmowanych jest wiele inicjatyw przez władze polskie, organizacje społeczne i samorządowe. Bałtycki plan działania HELCOM został przyjęty przez państwa basenu Morza Bałtyckiego. Inicjatywy na rzecz ochrony Morza Bałtyckiego realizowane są przy dużym wsparciu Unii Europejskiej i funduszy spójności. Ważną rolę odgrywają media społecznościowe, które wspierają prowadzone kampanie w ramach zachowania czystości wód Morza Bałtyckiego.

Na potrzeby niniejszego artykułu przeprowadzono badania ankietowe w 2016 i 2017 roku na próbie badawczej liczącej 100 osób. Dobór próby miał charakter celowy; ankietę skierowano do osób powyżej 18 lat. Badania dotyczyły wiedzy określającej poziom zaangażowania polskich władz w działania na rzecz zachowania czystości wód Morza Bałtyckiego oraz opinii dotyczącej oceny podejmowanych inicjatyw. Ankietę stanowiło 10 pytań problemowych oraz 2 pytania metryczkowe. W pierwszym pytaniu respondenci zostali poproszeni o wskazanie, czy są im znane akcje podejmowane na rzecz ochrony środowiska naturalnego Morza Bałtyckiego - 60 osób słyszało o takich inicjatywach, 30 osób nie słyszało o nich, a 10 respondentów stwierdziło: „trudno powiedzieć”. W kolejnym pytaniu uszczegółowiono wcześniejsze pytanie o znajomość akcji na rzecz ochrony środowiska Morza Bałtyckiego. Porównując odpowiedzi na pierwsze pytanie z odpowiedziami na drugie pytanie, stwierdzono, że zmniejszyła się liczba osób, które udzieliły twierdzącej odpowiedzi. Odpowiedź „tak” zaznaczyło 44 badanych, natomiast odpowiedź „nie” - 36 badanych; 20 osób stwierdziło, że nie potrafi w sposób jednoznaczny odpowiedzieć na to pytanie.

W odpowiedzi na pytanie o źródła informacji na temat ochrony środowiska naturalnego wskazano media tradycyjne - 32 osoby, internet - 28 osób, raporty specjalistyczne - 26 osób, inne - 10 osób, znajomych, ministerstwo - dwukrotnie. Na pytanie, co wzbudza szczególne zainteresowanie podczas oglądania kampanii społecznych poświęconych tematyce ochrony środowiska, 48 badanych wskazało na treści użyte w komunikacie marketingowym. Na szatę graficzną zwróciło uwagę 32 badanych, 12 osób wybrało podmiot organizujący kampanię, 8 osób wskazało inne czynniki. Kolejne pytanie dotyczyło czynników decydujących o powodzeniu promowanych idei kampanii społecznych - 28 ankietowanych wskazało „dotarcie do szerokiego grona odbiorców”, 26 osób - „posłużenie się efektywnymi nośnikami informacji”, 22 osoby - „wykorzystanie nowoczesnych technologii”, 10 - „inne”, a 14 - „odwoływanie się do autorytetów". Na pytanie dotyczące oceny efektywności kampanii społecznych organizowanych przez Ministerstwo Środowiska 40 respondentów odpowiedziało, iż efektywność ta jest na poziomie średnim, 2 osoby - że jest bardzo dobra, 4 - że jest dobra, 16 osób - że jest niska, 10 osób - że jest bardzo niska, 28 osób wskazało odpowiedź „trudno powiedzieć”. Odpowiadając na pytanie 7, respondenci mieli wskazać, czy uważają, że władze państwowe w pełni wykorzystują swoje możliwości dotyczące promowania działań na rzecz ochrony środowiska naturalnego - 56 osób zaznaczyło „nie”, „tak” wskazało 20 osób, „trudno powiedzieć" - 24 badanych. W pytaniu 8 uczestnicy badania zostali poproszeni o ocenę wizerunku Ministerstwa Środowiska w kontekście prowadzonych akcji - 44 osoby wizerunek Ministerstwa oceniło średnio, „bardzo dobrze” - 8 osób, „dobrze” - 10, „źle” - 12, „bardzo źle” - 10; odpowiedź „inne” wskazało 16 osób. Na pytanie, czy Ministerstwo Środowiska powinno zmienić sposób komunikacji marketingowej, 62 ankietowanych odpowiedziało, iż wymaga ona zmian; odpowiedź "nie” wybrało 30 badanych. Pozostali nie potrafili 
jednoznacznie określić swojego stanowiska. W ostatnim pytaniu proszono o wskazanie ewentualnych kierunków zmian dotyczących komunikacji marketingowej. „Większa obecność w mediach społecznościowych” - taką odpowiedź wskazało 48 osób, „większe zaangażowanie we współpracę z samorządami” - 6 osób, „większa częstotliwość organizowanych akcji” 40 osób, „inne” -6 osób.

Przeprowadzone badania z pewnością nie stanowią pełnego rozpoznania problemów związanych z ochroną wód Bałtyku i świadomością społeczną, jednak wskazują na wybrane aspekty rozważanej kwestii.

Uogólniając, należy stwierdzić, że Ministerstwo Środowiska nie wykorzystuje w pełni swojego potencjału; proponuje się, aby władze polskie zwiększyły swoją obecność w mediach społecznościowych, a także zintensyfikowały częstotliwość podejmowania akcji proekologicznych, by zwiększyć efektywność kampanii społecznych na rzecz zachowania czystości wód Morza Bałtyckiego.

\section{WNIOSKI I REKOMENDACJE}

$\mathrm{Na}$ podstawie analizy raportów, literatury przedmiotu oraz badań i obserwacji należy stwierdzić, że organy państwa powinny:

- stale inwestować środki na działania związane z ochroną środowiska naturalnego Morza Battyckiego;

- w ramach Komisji Ochrony Środowiska Morskiego Bałtyku (HELCOM, Komisja Helsińska) podejmować konkretne i odpowiedzialne działania w ramach bałtyckiego planu;

- realizować działania w ramach wymiaru północnego, w ramach którego przyjęto deklarację do realizacji przedsięwzięć mających na celu zapewnienie bezpieczeństwa morskiego, ochrony środowiska morskiego Morza Bałtyckiego, bioróżnorodności, zasobów rybnych i współpracy w zakresie polityki wodnej;

- rozliczyć realizację i wyciągnąć wnioski z kompleksowego programu przywrócenia równowagi ekologicznej Morza Bałtyckiego na lata 1993-1997 (I faza programu) i 1998-2012 (Il faza programu);

- monitorować projekty zrealizowane między innymi przez gminę Gdańsk, polegające na dążeniu do ograniczenia ładunków zanieczyszczeń wnoszonych do Bałtyku z obszaru miasta;

- poprzez Ministerstwo Środowiska oraz inne podmioty władzy publicznej wspierać oraz dotować kampanie społeczne oraz akcje proekologiczne na rzecz ochrony środowiska naturalnego Morza Bałtyckiego;

- monitorować ujścia rzek do Bałtyku;

- współpracować z państwami basenu Morza Bałtyckiego na rzecz poprawy czystości Bałtyku;

- organizować wspólne przedsięwzięcia proekologiczne ze wszystkimi zainteresowanymi rządami państw leżących nad Bałtykiem;

- wskazywać skutki i konsekwencje zanieczyszczeń, podnosząc świadomość ekologiczną społeczeństw basenu Morza Bałtyckiego.

Marketing ekologiczny pozwala zwrócić uwagę konsumentów, producentów, interesariuszy nie tylko na problem ochrony środowiska naturalnego, ale także na zwiększenie wiedzy oraz świadomości ekologicznej społeczeństwa. Podejmowanie inicjatyw oraz realizowanie działań 
jest jednym z narzędzi wykorzystywanych do promowania oraz kreowania pozytywnego wizerunku przedsiębiorstw, jednostek samorządów terytorialnych oraz instytucji publicznych.

Zasady marketingu ekologicznego stanowią istotny czynnik w podejmowaniu nowych inicjatyw na rzecz ochrony środowiska naturalnego. Poprzez ekomarketing przedsiębiorstwa, organizacje społeczne, rząd oraz jednostki samorządu terytorialnego powinny zwiększać wiedzę na temat działań, które muszą zostać podjęte lub zainicjowane, aby zostały zaspokojone proekologiczne potrzeby mieszkańców basenu Morza Bałtyckiego.

\section{PIŚMIENNICTWO}

Bałtycki Plan Działania, http://www.bsap.pl, dostęp: 19.10.2016.

Bomba na dnie Baltyku, http://biznes.onet.pl/wiadomosci/swiat/bomba-na-dnie-baltyku/n6nz76, dostęp: 18.10.2016.

Cechy morfometryczne, http://www.naszbaltyk.pl/cechy_morfometryczne.html, dostęp: 15.10.2016.

Düssel M. 2009. Marketing w praktyce. Warszawa, Wydaw.BC.edu.

Finał kampanii Bałtyk też może!, http://www.naszaziemia.pl/aktualnosci/baltyk-tez-moze-finalowyweekend-kampanii.html, dostęp: 1.11.2016.

Kiełczewski D. 1999. Ekologia społeczna. Białystok, Wydaw. Ekologia i Środowisko, 20.

Kozłowski S. 2005. Przyszłość ekorozwoju. Lublin, Wydaw. KUL, 49.

Leśniak J. 2001. Rola instrumentów marketingu ekologicznego we wdrażaniu rozwoju zrównoważonego na przykładzie Szwecji, w: Ekonomia, a zrównoważony rozwój. Tom 2. Red. F. Piontek. Białystok, Wydaw. Ekonomia i Środowisko, 87.

Małachowski K. 2011. Społeczne aspekty ochrony środowiska, w: Gospodarka, a środowisko i ekologia. Red. K. Małachowskiego. Warszawa, CeDeWu, 29.

Matczak P. 2000. Problemy ekonomiczne jako problemy społeczne. Poznań, Wydaw. UAM, 54.

$\mathrm{Na}$ ratunek środowisku, http://trojmiasto.wyborcza.pl/trojmiasto/1,72938,12683051,Na_ratunek_srodowisku.html\#ixzz4Nzd1sZSH, dostęp: 20.10.2016.

Raport z realizacji polityki morskiej RP w 2015 r., Warszawa 2016, Międzyresortowy Zespół do spraw Polityki Morskiej Rzeczypospolitej Polskiej, https://mgm.gov.pl/wp-content/uploads//2016/ 101/RAPORT_Z_REALIZACJI_POLITYKI_MORSKIEJ_RP_W_2015_ROKU_-_projekt_RM.pdf, dostęp: 17.10.2017.

Zaremba-Warnke S. 2009. Charakterystyka wybranych przejawów orientacji społecznej i humanistycznej, w: Marketing ekologiczny. Red. S. Zaremba-Warnke. Wrocław, Wydaw. UE Wroc., 89.

Streszczenie. Artykuł został poświęcony tematyce marketingu ekologicznego, a także działaniom, jakie realizuje państwo polskie w ramach zachowania czystości wód Morza Bałtyckiego. Przedstawiono inicjatywy realizowane przez władze polskie oraz wyniki sondażu diagnostycznego, które poprzedzone są częścią teoretyczną oraz analizą stanu środowiska naturalnego Morza Bałtyckiego. 
